\title{
Enhancement of water soluble wheat bran polyphenolic compounds using different steviol glucosides prepared by thermostable $\beta$-galactosidase
}

\section{Hee-jung Lim ${ }^{1}$, Thi Thanh Hanh Nguyen², Nahyun M. Kim ${ }^{3}$, Gha-hyun J. Kim Kyeonghwan Hwang ${ }^{5}$, Jun-Seong Park ${ }^{5}$, Atsuo Kimura ${ }^{6}$ and Doman Kim ${ }^{1,2 *}$}

${ }^{1}$ Graduate School of International Agricultural Technology, Seoul National University, Pyeongchang-gun, Gangwon-do, 25354, Korea; ${ }^{2}$ Research Institute of Food Industrialization, Institutes of Green Bio Science and Technology, Seoul National University, Pyeongchang-gun, Gangwon-do, 25354, Korea; ${ }^{3}$ Section of Neurobiology, Department of Biological Sciences, University of Southern California, Los Angeles, CA 90089, USA, ${ }^{4}$ School of Pharmacy, University of California, San Francisco, 500 Parnassus, San Francisco, CA 94143, USA, ${ }^{5}$ Skin Research Institute, Amorepacific Corporation R\&D Center, Yongin, 17074, Korea, ${ }^{6}$ Research Faculty of Agriculture, Hokkaido University, Sapporo 060-8589, Japan

*Corresponding author: Doman Kim, PhD, Graduate School of International Agricultural Technology, Seoul National University, Pyeongchang-gun, Gangwon-do, 25354, Korea

**The first two authors contributed equally to this work.

Submission Date: September 16, 2016, Accepted Date: October 25, 2016, Publication Date: October 30, 2016

Citation: Lim H.J., Nguyen T.T.H., Kim N.M., Kim G.J., Hwang K., Park J.S., Kimura A. and Kim D. Enhancement of water soluble wheat bran polyphenolic compounds using different steviol glucosides prepared by thermostable $\beta$-galactosidase. Functional Foods in Health and Disease 2016; 6(10):650-660

\begin{abstract}
:
Background: Production of wheat bran (WB) for human consumption is estimated to be about 90 million tons per year. WB contains an abundant source of dietary fiber, minerals, vitamins, and bioactive compounds. WB is a by-product of milling and contains an abundant source of carbohydrate $(60 \%)$, protein $(12 \%)$, fat $(0.5 \%)$, minerals $(2 \%)$, and bioactive compounds such as phenolic acids, arabinoxylans, flavonoids, caroteinoids alkylresorcinol and phytosterols. These are known for health promoting properties such as controlling glycemic index, reducing plasma cholesterol level, antioxidant, anti-inflammatory, and anticarcinogenic activities. Several terpene glycosides such as mogroside $\mathrm{V}$, paenoiflorin, geniposide, rubusoside (Ru), stevioside (Ste), rebaudioside A (RebA), steviol monoside, and stevioside glucoside have been discovered to enhance the solubility of a number of pharmaceutically and medically important compounds that normally show poor solubility in water.
\end{abstract}


Context and purpose of this study: In this study, in order to increase soluble extraction of polyphenol compounds of $\mathrm{WB}$ using $\mathrm{Ru}$, the expression of $\beta$-galactosidase from Thermus thermophilus ( $T$. thermophilus) was optimized using different $E$. coli hosts and a different concentration of lactose inducer rather than of isopropyl-1-thio- $\beta$-D-galactopyranoside (IPTG) for industrial production. Additionally, the effect of different steviol glucosides $(\mathrm{Ru}, \mathrm{Ste}, \mathrm{RebA}$, and $\mathrm{SG})$ on the enhancement of polyphenol compounds extraction from wheat bran was studied.

Results: $\beta$-galactosidase from $T$. thermophilus was used for the specific conversion of stevioside (Ste) to rubusoside ( $\mathrm{Ru}$ ) with $92 \%$ productivity. The enzyme was optimized to be expressed in $E$. coli. With $7 \mathrm{mM}$ lactose, the $\beta$-galactosidase activity expressed was $34.3,14.2$, or $34.4 \pm 0.5 \mathrm{U} / \mathrm{mL}$ in E. coli BL21(DE3)pLysS, Rosetta(DE3)pLysS, or BL21(DE3) at $37^{\circ} \mathrm{C}$, and $9.8 \pm 0.2,7.0 \pm 0.5$, or $7.4 \pm 0.2 \mathrm{U} / \mathrm{mL}$ at $28^{\circ} \mathrm{C}$ respectively. The expression of $\beta$-galactosidase was dependent on the lactose concentration and the highest activity was obtained with the conditions of $5 \mathrm{mM}$ lactose in E. coli $\operatorname{Rosetta(DE3)pLysS,~} 53.3 \pm 1.5 \mathrm{U} / \mathrm{mL}$. $78 \%$ of the mesophilic proteins was eliminated by heating at $70^{\circ} \mathrm{C}$ for 15 min with $89 \% \beta$-galactosidase activity recovery. The total polyphenol content of WB extracted by water, Ru, Ste, rebaudioside A (RebA), and steviol glucosides (SG) were $533.8 \pm 9.6 \mu \mathrm{g} / \mathrm{mL}, 633.3 \pm 1.25 \mu \mathrm{g} / \mathrm{mL}, 604.4 \pm 10.1 \mu \mathrm{g} / \mathrm{mL}, 654.8 \pm 26.5 \mu \mathrm{g} / \mathrm{mL}$, and 601.2 $\pm 33.4 \mu \mathrm{g} / \mathrm{mL}$, respectively. The $\mathrm{DPPH}$ radical scavenging activity prepared by water, $\mathrm{Ru}, \mathrm{Ste}$, RebA, and SG extraction were $8.76 \pm 0.3 \mathrm{mg} / \mathrm{mL}, 4.87 \pm 0.3 \mathrm{mg} / \mathrm{mL}, 5.34 \pm 0.22 \mathrm{mg} / \mathrm{mL}, 7.27 \pm$ $0.1 \mathrm{mg} / \mathrm{mL}$, and $7.82 \pm 0.02 \mathrm{mg} / \mathrm{mL}$ respectively.

Conclusions: To increase soluble extraction of polyphenol compounds of WB using $\mathrm{Ru}$, the expression of $\beta$-galactosidase from T. thermophilus was optimized using different $E$. coli hosts and a different concentration of lactose inducer rather than isopropyl-1-thio- $\beta$-D-galactopyranoside (IPTG) for industrial production of the enzyme. The highest antioxidant activity was shown in WB extracted by $\mathrm{Ru}$. The number of glucosyl units attached to steviol can possibly affect the efficiency of antioxidant activity of WB extracted by steviol glucosides.

Keywords: Rubusoside, $\beta$-galactosidase, lactose induction, immobilized enzyme, wheat bran, steviol glucosides

\section{INTRODUCTION:}

Wheat (Triticum aestivum) is a leading cereal crop primarily used for human consumption and livestock feed. A wheat kernel is comprised of three principal fractions: bran, germ, and endosperm, which makes up about 14-19\% of the whole wheat kernel [1]. Wheat bran (WB) is a by-product of milling and contains abundant source carbohydrate $(60 \%)$, protein $(12 \%)$, fat $(0.5 \%)$, minerals $(2 \%)$, and bioactive compounds such as phenolic acids, arabinoxylans, flavonoids, caroteinoids alkylresorcinol and phytosterols [1-3]. They are known for health promoting properties including controlling glycemic index, reducing plasma cholesterol level, and reducing the human colon cancer cell growth antioxidant, antimicrobial, anti-inflammatory, and anticarcinogenic activities [4-7].

Several terpene glycosides such as mogroside $\mathrm{V}$, paenoiflorin, geniposide, rubusoside $(\mathrm{Ru})$, stevioside (Ste), rebaudioside A (RebA), steviol monoside, and stevioside glucoside have been 
discovered to enhance the solubility of a number of pharmaceutically and medically important compounds which normally show poor solubility in water [8-10]. Steviol glucosides such as Ru, Ste, and RebA are the main sweet components of Rubus suavissimus S. Lee (Rosaceae) and Stevia rebaudiana Bertoni leaves [11]. Ste and RebA are isolated and extracted from the Stevia rebaudiana (bertoni) plant commercially cultivated in Japan, Singapore, Taiwan, South Korea, China, Israel, India, Brazil, Australia, and Paraguay [11]. Although Ru is not commercially available, Nguyen et al have developed a facile enzymatic process for preparing Ru from Ste by using $\beta$-galactosidase from $T$. thermophilus [12].

In this study, to increase soluble extraction of polyphenol compounds of WB using $\mathrm{Ru}$, the expression of $\beta$-galactosidase from $T$. thermophilus was optimized with different $E$. coli hosts and with different concentrations of lactose inducer rather than isopropyl-1-thio- $\beta$-Dgalactopyranoside (IPTG) for industrial production of the enzyme. Additionally, the effect of different steviol glucosides ( $\mathrm{Ru}$, Ste, RebA, and SG) on the enhancement of polyphenol compounds extraction from wheat bran was studied.

\section{MATERIALS AND METHODS:}

Preparation of $\beta$-galactosidase: The $\beta$-galactosidase gene, $\beta$-glypi, was ligated into the XhoI/EcoRI-digested pRSETB (pRSETB- $\beta$-GLYPI) vector as described in the previous study [12]. pRSETB- $\beta$-GLYPI was transformed and expressed in E. coli BL21(DE3)pLysS, E. coli Rosetta(DE3)pLysS, and E. coli BL21(DE3). Cells were grown in $100 \mathrm{~mL} \mathrm{LB}$ media containing $0.5 \%(\mathrm{w} / \mathrm{v})$ yeast extract, $1.0 \%(\mathrm{w} / \mathrm{v})$ tryptone, $1.0 \%(\mathrm{w} / \mathrm{v}) \mathrm{NaCl}$, and supplemented with ampicilin $(50 \mu \mathrm{g} / \mathrm{mL})$ in $500 \mathrm{~mL}$ flasks at $37^{\circ} \mathrm{C}$. The cells were induced with $7 \mathrm{mM}$ lactose when the optical density reached $\left(\mathrm{OD}_{600}\right) 0.5$ with $15 \mathrm{hrs}$ of shaking. The cells were collected by centrifugation ( $8000 \mathrm{xg}$ for $30 \mathrm{~min}$ at $4^{\circ} \mathrm{C}$ ), resuspended in $50 \mathrm{mM}$ Tris- $\mathrm{HCl} \mathrm{pH} \mathrm{7.0,} \mathrm{and} \mathrm{then} \mathrm{lysed} \mathrm{via} \mathrm{sonication}$ (Ultrasonic processor 250, Sonics and Materials, Inc., Newtown, CT, USA; output 30, for $1 \mathrm{~min}$, 4 repeat on ice). After centrifugation (12,000 x g for $30 \mathrm{~min}$ ), the clarified cell lysate was checked for enzyme activity using lactose as the substrate. The reaction mixture containing $200 \mathrm{mM}$ lactose and enzyme in $50 \mathrm{mM}$ Tris- $\mathrm{HCl} \mathrm{pH} 7.0$ was reacted at $70^{\circ} \mathrm{C}$ for $20 \mathrm{~min}$. The mixture was analyzed by thin layer chromatography (TLC) using precoated silica gel 60 F254 plates (Merck, Darmstadt, Germany) developed in a solvent system consisting of acetonitrile:water [85:15 (v/v)]. The plates were visualized by dipping into a solvent mixture of $0.5 \%(\mathrm{w} / \mathrm{v}) \mathrm{N}$-(1-naphthyl) ethylenediamine dihydrochloride and $5 \%(\mathrm{w} / \mathrm{v})$ sulfuric acid in methanol and heating at $120^{\circ} \mathrm{C}$ for $10 \mathrm{~min}$. The concentration of glucose released by $\beta$-galactosidase was analyzed using the integrated density values (IDV) derived by the AlphaEaseFC 4.0 program (Alpha Inotech, San Leandro, CA, USA) with glucose standard. One unit (U) of galactosidase activity is defined as the amount of enzyme required to release $1 \mu \mathrm{mol}$ glucose per minute under the above reaction conditions. E. coli BL21(DE3)pLysS was selected to determine the effect of lactose concentration for enzyme expression. The induction was carried out as described above with varying concentrations of lactose for induction $(1 \sim 7 \mathrm{mM})$ at $37^{\circ} \mathrm{C}$ for $15 \mathrm{hrs}$.

Large scale production of $\beta$-galactosidase was carried out in $19 \mathrm{~L}$ fermenter (Bioengineering AG., Riki, Switzerland) that contained 14 L LB media. The fermentation conditions were $37^{\circ} \mathrm{C}$, $250 \mathrm{rpm}$, and an aeration rate of $2 \mathrm{vvm}$. Cells were grown at $37^{\circ} \mathrm{C}$ until $\mathrm{OD}_{600}$ reached 0.6 , at which point $5 \mathrm{mM}$ lactose was added; the cells were harvested after $15 \mathrm{hrs}$. The cells were collected by 
centrifugation $\left(7,871 \mathrm{xg}\right.$ for $30 \mathrm{~min}$ at $\left.4^{\circ} \mathrm{C}\right)$, re-suspended in $500 \mathrm{~mL}$ of $50 \mathrm{mM}$ Tris- $\mathrm{HCl} \mathrm{pH} \mathrm{7.0,}$ and disrupted by sonication. The clarified cell lysate was obtained after centrifugation for $30 \mathrm{~min}$ at $12,000 \mathrm{x}$ g and partially purified $\beta$-galactosidase was heat treated at $70^{\circ} \mathrm{C}$ for $15 \mathrm{~min}$. Heatdenatured proteins were removed by centrifugation at $8,000 \mathrm{xg}$ for $15 \mathrm{~min}$. The supernatant was freeze dried for further study. The protein concentration was determined by the Bradford method with crystalline bovine serum albumin as the standard.

Production of rubusoside using double jacket columns: The $\beta$-galactosidase bead was prepared as described in the previous study [12] by mixing $300 \mathrm{U} / \mathrm{mL}$ of $\beta$-galactosidase with $2.5 \%$ $(\mathrm{w} / \mathrm{v})$ sodium alginate solution. The double jacket column reactors [Condenser, Liebig, with joint, $30 \times 3(\mathrm{~cm})$ in diameter] were filled with $\beta$-galactosidase beads. The reaction temperature was controlled using a heat circulator (EYELA, NCB-1200, Tokyo, Japan) at $70^{\circ} \mathrm{C}$. The reaction mixture containing $0.5 \%$ of Ste solution was pumped into the columns using a mini pump at the speed of $0.01 \mathrm{~mL}$ per min for $45 \mathrm{~g}$ Ste per day. The reaction mixture passed through columns and the fractions were collected into Eppendorf tubes. The Ru mixture was analyzed by TLC measuring integrated density values (IDV) derived from the AlphaEaseFC 4.0 program (Alpha Inotech, San Leandro, CA, USA) with purified $\mathrm{Ru}$ as the standard. Ru was purified as previously reported [12] by using Reveleris ${ }^{\circledR}$ Amino 120 g Flash Cartridges (Grace Discovery Science, Shanghai, China) with an evaporative light scattering detector (ELSD, Grace Discovery Science, Shanghai, China). A mixture of acetonitrile and water was used as an eluent with the gradient from 99:1 (v/v) to $50: 50(\mathrm{v} / \mathrm{v})$ of acetonitrile: water at a flow rate of $60 \mathrm{~mL} / \mathrm{min}$ at room temperature. The purified Ru was collected and freeze dried for further study.

Extraction of wheat bran using different steviol glucosides: Wheat bran was kindly supplied by the Sajo Donga One Corporation (Seoul, Korea). RebA and SG with $\alpha-1-4$ linkages were provided by Daepyung Co., Ltd (Gyeonggi-do, Korea). WB-Ru (wheat bran powder treated with $\mathrm{Ru}$ to solubilize polyphenol), WB-Ste (wheat bran powder treated with Ste to solubilize polyphenol), WB-Reb (wheat bran powder treated with RebA to solubilize polyphenol), and WBSG (wheat bran powder treated with SG to solubilize polyphenol) solutions were prepared as previously reported $[10,12]$ with some modifications. Each Ste, RebA, or SG at $10 \%(\mathrm{w} / \mathrm{v})$ and $\mathrm{Ru}$ at $2 \%(\mathrm{w} / \mathrm{v})$ was mixed with $20 \%(\mathrm{w} / \mathrm{v})$ of WB powder, followed by the addition of ethanol. The mixture in ethanol solution was vortexed for $15 \mathrm{~min}$ and centrifuged at $12,000 \mathrm{xg}$ for $10 \mathrm{~min}$. The supernatant was transferred to a new tube and ethanol was evaporated [10,12]. The resulting powders were dissolved in water, centrifuged at $12,000 \mathrm{x}$ g for $10 \mathrm{~min}$, and filtered through 0.20 $\mu \mathrm{m}$ membrane (Agilent, Santa clara, CA, USA). TLC with an ascent of acetonitrile/water 85:15 $(\mathrm{v} / \mathrm{v})$ was used for the analysis of compounds. Polyphenol compounds on silica gel $60 \mathrm{~F}_{254}$ TLC plate (Merck, Darmstadt, Germany) were visualized under $\mathrm{UV}_{254 \mathrm{~nm}}$ and by dipping the TLC plate into a solvent mixture of $0.5(\mathrm{w} / \mathrm{v}) \mathrm{N}-(1$-naphthyl) ethylenediamine dihydrochloride and $5 \%(\mathrm{w} / \mathrm{v})$ sulfuric acid in methanol followed by heating at $121^{\circ} \mathrm{C}$ for $10 \mathrm{~min}$. The WB extracted using the same method but without the addition of steviol glucosides served as the control. 
Determination of total phenols content: The total polyphenols content in each extraction sample was determined by using Folin-Ciocalteu reagent with gallic acid as the standard (Sigma) [13]. $120 \mu \mathrm{L}$ of samples and gallic acid $(1 \sim 50 \mu \mathrm{g} / \mathrm{mL})$ were added into the 96 well plate and $15 \mu \mathrm{L}$ Follin-Ciocalteu reagent (Sigma) was mixed for $3 \mathrm{~min} .15 \mu \mathrm{L}$ of $10 \%$ (w/v) $\mathrm{Na}_{2} \mathrm{CO}_{3}$ was then added and reacted with the samples for $30 \mathrm{~min}$ at dark condition. The phenol content was determined using SpectraMax M3 (Molecular Devices, Sunnyvale, CA, USA) at $760 \mathrm{~nm}$.

Antioxidant activity: The antioxidant activities of water soluble polyphenol of WBs prepared with different steviol glucosides were evaluated by 2,2-diphenyl-1-picrylhydrazyl (DPPH) radical scavenging method [14]. Samples were dissolved in water and mixed with $100 \mu \mathrm{M}$ (DPPH) in methanol solution to give a final concentration of 0.2 to $12 \mathrm{mg}$ WB extracted powder by $\mathrm{Ste}, \mathrm{Ru}$, Reb, or SG $/ \mathrm{mL}$. After $30 \mathrm{~min}$ of incubation at $25^{\circ} \mathrm{C}$ in total darkness, the absorbance of each mixture was measured at $517 \mathrm{~nm}$ on a microplate reader (Molecular Devices, Sunnyvale, CA, USA). A mixture containing all reagents except the test sample was used as a negative control for this test. DPPH radical-scavenging activity was converted to percentage of antioxidant activity using the following equation:

DPPH radical-scavenging activity $(\%)=$

$\frac{\text { (Absorbance of control-Absorbance of test sample) }}{\text { Absorbance of control }} \times 100$

A linear regression curve was established in order to determine the $\mathrm{SC}_{50}$ value which is the amount of sample necessary to decrease $50 \%$ of the DPPH absorbance. All analyses were carried out in triplicates. Results were expressed as mean \pm standard deviation (SD). Statistical significance was considered when $\mathrm{p}<0.05$.

\section{RESULTS AND DISCUSSION:}

Optimization for the expression of $\boldsymbol{\beta}$-galactosidase: Table 1 shows the $\beta$-galactosidase activity from T. thermophilus expressed in E. coli BL21(DE3)pLysS, E. coli Rosetta(DE3)pLysS, and $E$. coli $\mathrm{BL} 21(\mathrm{DE} 3)$ at $28^{\circ} \mathrm{C}$ or $37^{\circ} \mathrm{C}$. The expressed $\beta$-galactosidase activity was $34.3,14.2$, or 34.4 $\pm 0.5 \mathrm{U} / \mathrm{mL}$ in $E$. coli BL21(DE3)pLysS, E. coli Rosetta(DE3)pLysS, or E. coli BL21(DE3) at $37^{\circ} \mathrm{C}$, and $9.8 \pm 0.2,7.0 \pm 0.5$, or $7.4 \pm 0.2 \mathrm{U} / \mathrm{mL}$ at $28^{\circ} \mathrm{C}$, respectively. The $\beta$-galactosidase activity at $37^{\circ} \mathrm{C}$ induction was 3.5 fold greater in E. coli BL21(DE3)pLysS expression, 2.0 fold greater in E. coli Rosetta(DE3)pLysS expression, and 4.7 fold greater in E. coli BL21(DE3) expression than those at $28^{\circ} \mathrm{C}$ induction. The E. coli BL21(DE3)pLysS was selected for the investigation of the lactose concentration effect of the $\beta$-galactosidase expression (Table 2) based on the similarity in $\beta$-galactosidase activity expressed in $E$. coli BL21(DE3)pLysS and E. coli BL21(DE3). $\beta$ galactosidase activity was increased from $19.1 \pm 0.7 \mathrm{U} / \mathrm{mL}$ to $53.3 \pm 1.5 \mathrm{U} / \mathrm{mL}$ when the concentration of lactose inducer was increased from 1 to $5 \mathrm{mM}$. For lactose induction concentrations above $5 \mathrm{mM}$, the $\beta$-galactosidase activity expressed was decreased to $48.4 \pm 1.7$ $\mathrm{mM}$. Hence, the selected lactose concentration for induction was $5 \mathrm{mM}$. 
Table 1. $\beta$-galactosidase activity expressed from different $E$. coli at $7 \mathrm{mM}$ lactose induction

\begin{tabular}{cccc} 
Temperature & $\begin{array}{c}\text { E. coli BL21 } \\
(\mathbf{D E 3}) \mathbf{p L y s S} \\
(\mathbf{U} / \mathbf{m L})\end{array}$ & $\begin{array}{c}\text { E. coli } \\
\text { Rosetta }(\mathbf{D E 3}) \mathbf{p L y s S} \\
(\mathbf{U} / \mathbf{m L})\end{array}$ & $\begin{array}{c}\text { E. coli BL21 (DE3) } \\
(\mathbf{U} / \mathbf{m L})\end{array}$ \\
\hline $28^{\circ} \mathrm{C}$ & $9.8 \pm 0.2$ & $7.0 \pm 0.5$ & $7.4 \pm 0.2$ \\
$37^{\circ} \mathrm{C}$ & $34.3 \pm 0.0$ & $14.2 \pm 0.3$ & $34.4 \pm 0.5$ \\
\hline
\end{tabular}

One unit (U) of $\beta$-galactosidase activity is defined as the amount of enzyme required to release 1 $\mu \mathrm{mol}$ glucose per min under the above reaction conditions.

Table 2. $\beta$-galactosidase activity expressed from $E$. coli BL21(DE3)pLysS with lactose induction

\begin{tabular}{ll}
$\begin{array}{l}\text { Lactose concentration } \\
(\mathbf{m M})\end{array}$ & $\begin{array}{l}\text { Activity } \\
\mathbf{( U / m L )}\end{array}$ \\
\hline 1 & $19.1 \pm 0.7$ \\
2 & $22.3 \pm 2.2$ \\
3 & $46.6 \pm 0.0$ \\
5 & $53.3 \pm 1.5$ \\
7 & $48.4 \pm 1.7$ \\
\hline
\end{tabular}

The reaction mixture containing $200 \mathrm{mM}$ lactose, enzyme in $50 \mathrm{mM}$ Tris- $\mathrm{HCl} \mathrm{pH} 7.0$ was reacted at $70^{\circ} \mathrm{C}$ for $20 \mathrm{~min}$. One unit (U) of $\beta$-galactosidase activity is defined as the amount of enzyme required to release $1 \mu \mathrm{mol}$ glucose per min under the above reaction conditions.

Compared to mesophilic enzymes, thermostable enzymes exhibiting maximal activity at temperatures ranging from 70 to $90^{\circ} \mathrm{C}$ have significant advantages, including greater reaction velocity, reduced risk of microbial contamination, and longer enzyme half-lives under operational conditions $[15,16]$. After the heating of crude $\beta$-galactosidase solution, $78 \%$ of the mesophilic proteins were eliminated with $89 \% \beta$-galactosidase activity recovery (Table 3 ). The partially purified $\beta$-galactosidase demonstrated a specific activity of $23 \mathrm{U} / \mathrm{mg}$ corresponding to a 4 -fold purification.

Table 3. Partial purification of $ß$-galactosidase

\begin{tabular}{lcccccc}
\hline & $\begin{array}{c}\text { Total } \\
\text { volume } \\
(\mathbf{m L})\end{array}$ & $\begin{array}{c}\text { Total } \\
\text { protein } \\
(\mathbf{m g})\end{array}$ & $\begin{array}{c}\text { Total unit } \\
(\mathbf{U})\end{array}$ & $\begin{array}{c}\text { Specific } \\
\text { activity } \\
\mathbf{( U / m g )}\end{array}$ & $\begin{array}{c}\text { Purification } \\
(\mathbf{f o l d})\end{array}$ & $\begin{array}{c}\text { Yield } \\
(\mathbf{\%})\end{array}$ \\
\hline Crude enzyme & 2,000 & $35,814.9$ & 204,000 & 5.7 & 1 & 100 \\
After Heat treatment & 1,650 & $7,885.0$ & 181,500 & 23.0 & 4 & 89.0 \\
\hline
\end{tabular}

Partially purified $\beta$-galactosidase was heat treated at $70^{\circ} \mathrm{C}$ for $15 \mathrm{~min}$. Heat-denatured proteins were removed by centrifugation at $8,000 \mathrm{x}$ g for $15 \mathrm{~min}$. The reaction mixture containing $200 \mathrm{mM}$ lactose, enzyme in $50 \mathrm{mM}$ Tris- $\mathrm{HCl} \mathrm{pH} 7.0$ was reacted at $70^{\circ} \mathrm{C}$ for $20 \mathrm{~min}$. One unit (U) of $\beta$ - 
galactosidase activity is defined as the amount of enzyme required to release $1 \mu$ mol glucose per min under the above reaction conditions.

Production of rubusoside using immobilized $\boldsymbol{\beta}$-galactosidase on double jacket columns:

The free enzyme reaction was carried out by mixing $0.5 \%(\mathrm{w} / \mathrm{v})$ Ste and $300 \mathrm{U} / \mathrm{mL}$ in $50 \mathrm{mM}$ Tris$\mathrm{HCl} \mathrm{pH} 7.0$ at $70^{\circ} \mathrm{C}$ in a water bath for $12 \mathrm{hrs}$. By using free enzyme, the amount of Ru produced was $3.3 \mathrm{~g} / \mathrm{L}$ and the Ste conversion was $74.3 \%$. For the double jacket column, the reaction was carried for 31 days. The amount of Ru released from Ste is shown in Table 4. The total amount of Ru produced was $738.67 \mathrm{~g}$ for 31 days. Immobilized enzyme demonstrated $77 \%$ activity up to 21 days and then the activity gradually reduced in the span of 31 days, while still maintaining $51.4 \%$ $\beta$-galactosidase activity (Table 4).

Total polyphenol content of wheat bran extract: Figure 1 shows the total polyphenol content of the WB extracts measured using the Folin-Ciocalteu method. Total polyphenol values were obtained from the calibration curve, $\mathrm{y}=0.0256 \mathrm{x}-0.0133$ with $R^{2}=0.9993$ where $\mathrm{x}$ is the absorbance and $y$ is the concentration of gallic acid (GAE) solution $(\mu \mathrm{g} / \mathrm{mL})$. The total polyphenol values of the WB extracts were $533.8 \pm 9.6 \mu \mathrm{g} / \mathrm{mL}$ for WB extracted by ethanol, $633.3 \pm 1.25$ $\mu \mathrm{g} / \mathrm{mL}$ for WB extracted by $\mathrm{Ru}, 604.4 \pm 10.1 \mu \mathrm{g} / \mathrm{mL}$ for WB extracted by Ste, $654.8 \pm 26.5 \mu \mathrm{g} / \mathrm{mL}$ for WB extracted by RebA, and $601.2 \pm 33.4 \mu \mathrm{g} / \mathrm{mL}$ for WB extracted by SG. The total polyphenol values of WB extracted by Ru, Ste, RebA, and SG were 1.19, 1.13, 1.23, and 1.13 fold greater than that of WB extracted by water. Interestingly, while $2 \%(\mathrm{w} / \mathrm{w})$ of Ru was used for the extraction of polyphenol from WB powder and 10\% (w/w) of Ste, RebA, and SG were used, the total polyphenol content of WB extracted by Ru $(633.3 \pm 1.25 \mu \mathrm{g} / \mathrm{mL})$ was greater than those of WBs extracted by Ste $(604.4 \pm 10.1 \mu \mathrm{g} / \mathrm{mL})$ and SG $(601.2 \pm 33.4 \mu \mathrm{g} / \mathrm{mL})$ but lower than WB extracted by RebA $(654.8 \pm 26.5 \mu \mathrm{g} / \mathrm{mL})$. These results suggest that $\mathrm{Ru}$, Ste, RebA and $\mathrm{SG}$ could be used for enhancing the solubility of polyphenol compounds from WB extracted in water.

Table 4. Stability of the immobilized enzyme during double jacket columns reaction

\begin{tabular}{|c|c|c|}
\hline Day* & $\begin{array}{l}\text { The amount of } \mathrm{Ru} \text { production** } \\
\text { ( } \mathrm{g} / \text { day) }\end{array}$ & Immobilized enzyme stability (\%) \\
\hline 6 & $31.3 \pm 5.3$ & 100 \\
\hline 8 & $26.7 \pm 8.6$ & 85.1 \\
\hline 11 & $28.9 \pm 3.5$ & 92.3 \\
\hline 12 & $26.1 \pm 6.1$ & 83.3 \\
\hline 14 & $24.4 \pm 6.0$ & 77.9 \\
\hline 16 & $25.5 \pm 0.1$ & 81.4 \\
\hline 19 & $27.4 \pm 3.1$ & 87.3 \\
\hline 21 & $24.4 \pm 3.0$ & 78.0 \\
\hline 22 & $18.1 \pm 0.9$ & 57.9 \\
\hline 28 & $16.9 \pm 3.2$ & 54.0 \\
\hline 29 & $17.1 \pm 0.1$ & 54.5 \\
\hline 31 & $16.1 \pm 1.4$ & 51.4 \\
\hline
\end{tabular}

*The reaction was carried on for 1 month.

**45 $\mathrm{g}$ of Ste was totally used per day. The theoretical maximum amount of Ru production was $36 \mathrm{~g}$ per day. 


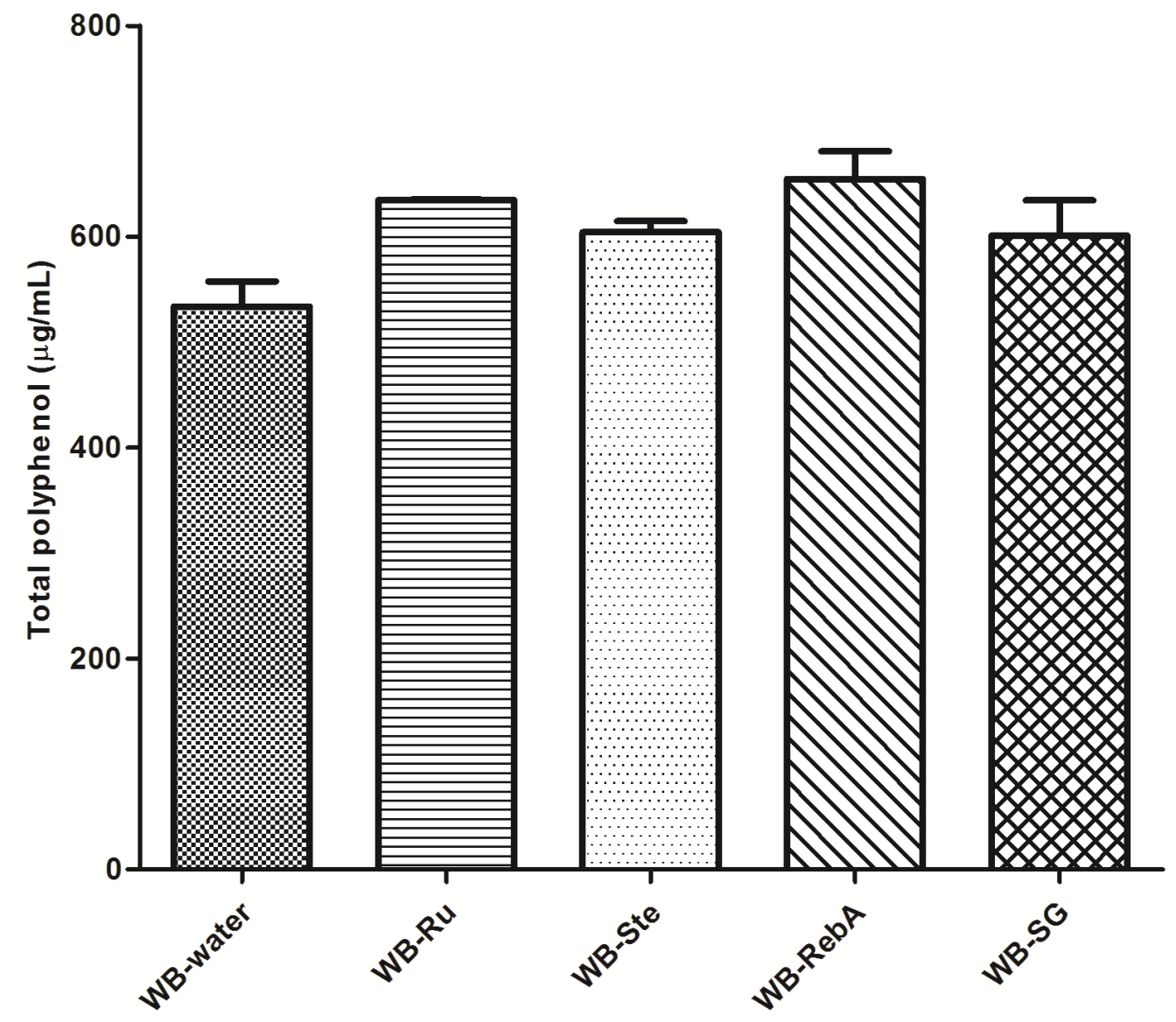

Fig. 1. The amount of water soluble polyphenol obtained from wheat bran powder by using different steviol glucosides.

Antioxidant activity: Antioxidant activity of water soluble WB extracted using different steviol glucosides was compared using a free radical-scavenging method of DPPH with $\mathrm{SC}_{50}$ values representing antioxidant activity. The $\mathrm{SC}_{50}$ values of water soluble $\mathrm{WB}$ prepared with water, $\mathrm{Ru}$, Ste, RebA, and SG were $8.76 \pm 0.3 \mathrm{mg} / \mathrm{mL}, 4.87 \pm 0.3 \mathrm{mg} / \mathrm{mL}, 5.34 \pm 0.22 \mathrm{mg} / \mathrm{mL}, 7.27 \pm 0.1$ $\mathrm{mg} / \mathrm{mL}$, and $7.82 \pm 0.02 \mathrm{mg} / \mathrm{mL}$, respectively (Figure. 2). The WB extracted by Ru, Ste, RebA, and SG showed higher antioxidant activity compared to WB extracted by water. The highest antioxidant activity was shown in WB extracted by Ru. The antioxidant activity order of WB extracted by steviol glucosides is as follows: WB-Ru $>$ WB-Ste $>$ WB-RebA $>$ WB-SG. Ste, RebA, and SG are glycosides on aglycone's carbon skeleton of steviol. Ste, RebA, and SG have a Dglucose group affixed at $\mathrm{C}_{19}$. Additionally, Ste has a di-glucosyl while RebA has a tri-glucosyl sugar moiety affixed at $\mathrm{C}_{13}$. SG is glycoside mixture of steviol. An inverse relationship was demonstrated between the glucosyl unit and antioxidant activity. Thus, the number of glucosyl units attached to steviol can possibly affect the efficiency of antioxidant activity of WB extracted by steviol glucosides. 


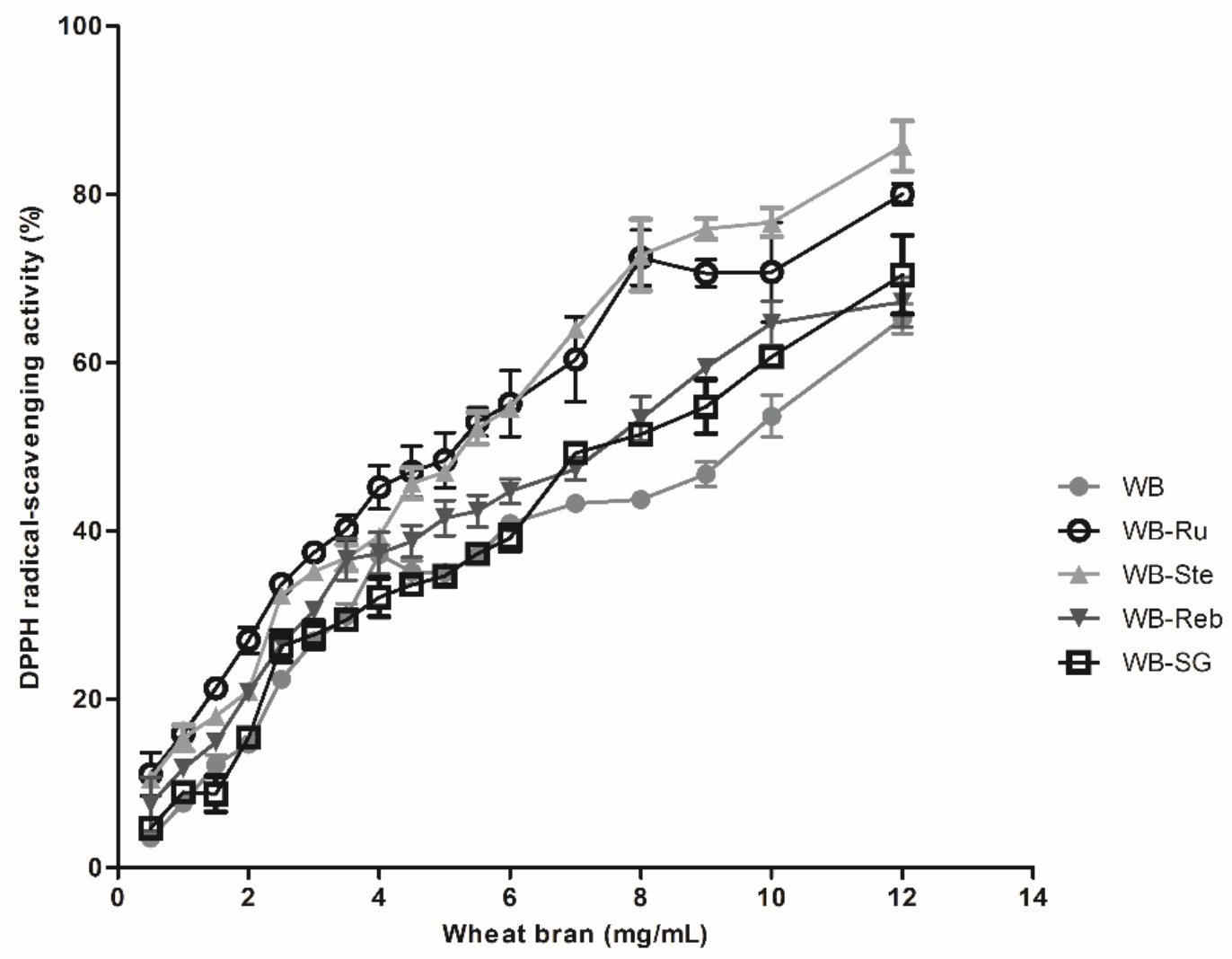

Fig. 2 The antioxidant activity of water soluble WB extracts prepared by using different steviol glucosides.

CONCLUSIONS: To increase soluble extraction of polyphenol compounds of WB using Ru, the expression of $\beta$-galactosidase from $T$. thermophilus was optimized using different $E$. coli hosts and a different concentration of lactose inducer rather than isopropyl-1-thio- $\beta$-D-galactopyranoside (IPTG) for industrial production of the enzyme. The highest antioxidant activity was shown in WB extracted by $\mathrm{Ru}$. The number of glucosyl units attached to steviol can possibly affect the efficiency of antioxidant activity of WB extracted by steviol glucosides.

Abbreviation: WB, wheat bran; DMSO, dimethyl-sulfoxide; DPPH, 2,2-diphenyl-1-picrylhydrazyl-hydrate; Reb A, rebaudioside A; Ste, stevioside; Ru, rubusoside; SG, steviol glucosides; $\mathrm{SC}$, DPPH radical-scavenging activity; WB-Ru, wheat bran powder treated with $\mathrm{Ru}$ to solubilize polyphenol; WB-Ste, wheat bran powder treated with Ste to solubilize polyphenol; WB-Reb, wheat bran powder treated with RebA to solubilize polyphenol; WB-SG, wheat bran powder treated with SG to solubilize polyphenol

Authors' Contributions: All authors contributed to this study.

Acknowledgements: This work was partially supported by Agriculture, Food and Rural Affairs Research Center Support Program, Ministry of Agriculture, Food and Rural Affairs, Republic of Korea (D. Kim), by the Basic Science Research Program through the National Research 
Foundation of Korea (NRF) funded by the Ministry of Education (T.T. Hanh Nguyen), under the framework of International Cooperation Program managed by the NRF (2016K2A9A2A08003613), and by Amorepacific Corporation through Research and Publication Projects.

\section{REFERENCES:}

1. Javed MM, Zahoor S, Shafaat S, Mehmooda I, Gul A, Rasheed H, Bukhari SAI, Aftab MN, Ikram-ul-Haq: Wheat bran as a brown gold: Nutritious value and its biotechnological applications. Afr J Microbiol Res 2012, 6(4):724-733.

2. Onipe OO, Jideani AIO, Beswa D: Composition and functionality of wheat bran and its application in some cereal food products. Int J Food Sci Tech 2015, 50(12):2509-2518.

3. Slavin J: Why whole grains are protective: biological mechanisms. Proc Nutr Soc 2003, 62(1):129-134.

4. Pruckler M, Siebenhandl-Ehn S, Apprich S, Holtinger S, Haas C, Schmid E, Kneifel W: Wheat bran-based biorefinery 1: Composition of wheat bran and strategies of functionalization. Lwt-Food Sci Technol 2014, 56(2):211-221.

5. Jensen MK, Koh-Banerjee P, Franz M, Sampson L, Gronbaek M, Rimm EB: Whole grains, bran, and germ in relation to homocysteine and markers of glycemic control, lipids, and inflammation 1. Am J Clin Nutr 2006, 83(2):275-283.

6. Liu L, Winter KM, Stevenson L, Morris C, Leach DN: Wheat bran lipophilic compounds with in vitro anticancer effects. Food Chem 2012, 130(1):156-164.

7. Brouns F, Hemery Y, Price R, Anson NM: Wheat aleurone: separation, composition, health aspects, and potential food use. Crit Rev Food Sci 2012, 52(6):553-568.

8. Zhang F, Koh GY, Hollingsworth J, Russo PS, Stout RW, Liu Z: Reformulation of etoposide with solubility-enhancing rubusoside. Int J Pharm 2012, 434(1-2):453-459.

9. Zhang F, Koh GY, Jeansonne DP, Hollingsworth J, Russo PS, Vicente G, Stout RW, Liu ZJ: A Novel solubility-enhanced curcumin formulation showing stability and maintenance of anticancer activity. J Pharm Sci-Us 2011, 100(7):2778-2789.

10. Nguyen TT, Si J, Kang C, Chung B, Chung D, Kim D: Facile preparation of water soluble curcuminoids extracted from turmeric (Curcuma longa L.) powder by using steviol glucosides. Food Chem 2017, 214:366-373.

11. Upreti M, Strassburger K, Chen YL, Wu SX, Prakash I: Solubility enhancement of steviol glycosides and characterization of their inclusion complexes with gamma-cyclodextrin. Int J Mol Sci 2011, 12(11):7529-7553.

12. Nguyen TT, Jung SJ, Kang HK, Kim YM, Moon YH, Kim M, Kim D: Production of rubusoside from stevioside by using a thermostable lactase from Thermus thermophilus and solubility enhancement of liquiritin and teniposide. Enzyme Microb Technol 2014, 6465:38-43.

13. Farasat M, Khavari-Nejad RA, Nabavi SM, Namjooyan F: Antioxidant activity, total phenolics and flavonoid contents of some edible green seaweeds from Northern Coasts of the Persian Gulf. Iran J Pharm Res 2014, 13(1):163-170. 
14. Kang J, Kim YM, Kim N, Kim DW, Nam SH, Kim D: Synthesis and characterization of hydroquinone fructoside using Leuconostoc mesenteroides levansucrase. Appl Microbiol Biotechnol 2009, 83(6):1009-1016.

15. Petzelbauer I, Nidetzky B, Haltrich D, Kulbe KD: Development of an ultra-hightemperature process for the enzymatic hydrolysis of lactose. I. The properties of two thermostable beta-glycosidases. Biotechnol Bioeng 1999, 64(3):322-332.

16. Maciunska J, Scibisz M, Synowiecki J: Stability and properties of a thermostable betagalactosidase immobilized on chitin. J Food Biochem 2000, 24(4):299-310. 